\title{
Legal-political frameworks that promote Social and Solidarity Economy in Colombia and Mexico. A comparative cartography*
}

\author{
Marcos jurídico-políticos que fomentan la Economía Social y \\ Solidaria en Colombia y México. Una cartografía comparada
}

\author{
Raquel Ortiz-Ledesma \\ University of Deusto \\ raquel.ortizle@deusto.es
}

Summary: Introduction. 1. Background: SSE objectives and evolution of the SSE recognition. 2. Compared analysis of Social Economy Legal Frameworks in America. 3. Discussions of the analysis. 4. Conclusions. 5. References.

Abstract: This article analyses the relevance of the legal-political frameworks of Social and Solidarity Economy (SSE) to social transformation. The article is divided into three sections where the international evolution of the legal-political frameworks and the different types of categorization of the legal framework for SSE support will be discussed. In addition, through documentary research and a comparison on legal frameworks and national public policies, the implementation of those frameworks in two States from The Americas, Colombia and Mexico, will be considered. This article concludes by highlighting the challenges of SSE and some possible route maps, as well as the relevance of this framework to social change.

Keywords: legal-political frameworks, SSE recognition, Public policies analysis.

Resumen: Este artículo analiza la relevancia de los marcos jurídicopolíticos de la Economía Social y Solidaria (ESS) para la transformación social. El trabajo se estructura en tres secciones donde se examinará la evolución internacional de los marcos jurídico-políticos y los diferentes tipos de

* Citation: Ortiz-Ledesma, Raquel. 2019. “Legal-political frameworks that promote Social and Solidarity Economy in Colombia and Mexico. A comparative cartography". Deusto Journal of Human Rights, no. 4: 87-114. http://dx.doi.org/18543/ djhr-4-2019pp87-114 
categorización del marco legal para la promoción de la ESS. Además, a través de la investigación documental y la comparación del marco legal y las políticas públicas, se analizará la implementación de dichos marcos en dos Estados de América: Colombia y México. Este trabajo concluye subrayando los desafíos de la ESS y una posible ruta a seguir, así como la relevancia de estos marcos para el cambio social.

Palabras clave: marcos jurídico-políticos, reconocimiento de la ESS, análisis de políticas públicas. 


\section{Introduction 1}

In a world where it seems that human rights are often overlooked, there are several circumstances that further inhibit the belief that the world's current situation is promising. Many people living on less than two dollars a day, inequality spreading all over the world, young people struggling to find a job, new health challenges arising every day, increasing environmental degradation and rising threats of extremist violence are just some examples of the instability the world is facing right now. Today, the concept of sustainability does not only relate to economic growth, but to a more comprehensive vision put forward by the United Nations through the Sustainable Development Goals (SDGs). Built upon on three key dimensions - social, environmental and economic - the SDGs seek to influence policy makers to promote fairer societies and transform social reality to guarantee social, economic, political and cultural rights. Following the mixed results from the UN's former development agenda, known as the Millennium Development Goals (MDGs), the 2030 agenda maintains the transversal goal of leaving no one behind. The SDGs' focus on individuals as well as on environmental challenges has also placed the Social and Solidarity Economy (hereafter referred to as SSE) as a key element for transformative change and to implement the SDGs (Utting 2018). The SSE is seen as an alternative solution to the current challenges, placing strong emphasis on human beings and going against the values of the neoliberal system. The SSE can play a role in dignifying people's lives, but this will only occur through the recognition of the sector at the global level; and especially, a specific and adaptive legal framework that recognizes the sector (García 2009)2. During the last decades, some efforts at the international level have resulted in the design and implementation of legal-political frameworks that support SSE. These efforts are the starting point to promote the respect of people's dignity, and with that, guarantee their human rights. However, some questions arise in this regard. It would be important to question first what the design and formulation processes of the legal-political frameworks that

1 The research basis of this article has been supported with the Grants Programme for Research Staff Training at the University of Deusto in 2018 and from R \& D \& i MINECO/FEDER Project, Spanish Ministry of Economy and Competitiveness, and European Regional Development Fund: 'Complex inequality in plural societies. Public policy indicators' [DER 2016-77711-P].

2 García explains the guidelines that legal frameworks should follow in order to design appropriate juridical recognition of the SSE based in the research of three different countries: Venezuela, Colombia and Mexico (2009). 
support SSE from a legal and political perspective has been. Second, to understand which elements have been considered in the formulation of legal frameworks and in the implementation of public policies? Finally, to question where these legal and political frameworks should head towards when promoting sustainable development.

The article will try to provide answers to the previous questions. First, a review will be carried out on the background of the political and legal recognition of the SSE at the international level. The paper will also provide a categorization according to the areas of influence that have existed in the legal frameworks supporting SSE. Secondly, two countries with legal-political frameworks that support SSE have been selected and, in accordance with the identification variables for the analysis, a comparison will be made between those countries by looking at the implementation of legal frameworks and public policies in each country ${ }^{3}$. The criteria to select both countries considers many aspects such as the competence level of the legal frameworks in both countries at the national level, the importance of legal frameworks in the development structure, the similarities of the SSE role in their social conflict contexts ${ }^{4}$, and the strategic role of SSE in each National Development Plan. We also look at the differences in the trajectories of SSE in each country. For instance, the Colombian legal framework was created on 1998, while the Mexican legal framework was created almost fifteen years later with the implementation of the Law on Social and Solidarity Economy (LESS for its acronym in Spanish).

The methodology is based on a comparative method in both countries. An analysis of public policies and legal frameworks, as well

3 For this article, the author analyzed different types of legal frameworks and public policies from different States. The research was for performed on nineteen different countries, followed by a more specific selection process. The result was a final selection composed by the following countries: Argentina, Brazil, and Uruguay (cooperative legal frameworks); Finland, Slovenia, Luxembourg, Italy (social enterprise legal frameworks); and Colombia, Venezuela, Ecuador, Honduras (solidarity economy legal frameworks). In the case of regional legal frameworks (competency level) the analyzed cases were the Wallonia region and the Quebec region. Also, the legal frameworks for SSE support at the national level were the following: Spain, Mexico, France, Portugal, Greece, and Romania.

4 Castillo (2017) analyzes the SSE impact of violence situations in Mexico in "LoS movimientos de economía social y solidaria en zonas de conflicto armado en México". In addition, the author edited the book Economía social en contextos de violencia: México y Colombia, that shows some examples of the SSE implementation on violent zones in Mexico (Guerrero, Michoacán, Puebla) and Colombia (the social reinsertion of the Colombian Revolutionary Armed Forces as established in the Peace accords) (Castillo 2018). 
as content analysis from diverse bibliographic and documental research were conducted in order to find similarities, differences, positive aspects and areas of improvement in both cases. The concepts used for the comparison of the legal framework are the following: objectives of the legal framework; the presence of Constitutional recognition of the social sector; the entities that integrate the SSE sector according to the Law; the national bodies established by legal frameworks to promote SSE at the domestic level and the policies developed for the promotion; and finally, the evaluation mechanisms that each country has established in order to monitor SSE promotion at the national level.

In addition, the concepts used in the public policies comparison are based on the Chaves (2013) proposal about the aspects that are considered in SSE public policies: the presence of programmatic and structural policies; the implementation of hard policies and soft policies in each country for supporting the SSE sector. This information will allow us to look into both the similarities and differences, as well as the strengths and weaknesses in each of the legal-political frameworks analyzed. Through this analysis, we aim to identify the challenges that currently exist for the design and implementation of legal-political frameworks for the promotion of the SSE.

\section{Background: SSE Objectives and evolution of the SSE recognition}

Over the past few decades and due to the economic crisis caused by the neoliberal system, the Social and Solidarity Economy has garnered special attention. In 1970, the Club of Rome's report "The limits of Growth" pointed out the unsustainable character of the current system, noting the incompability of infinite growth with a finite world (Poirier et al. 2018, 2). By 1980, Spain and France pioneered the design of specific policies to promote the social economy sector, which was known at that time as the third institutional sector (Chaves 2013, 57). In 1997, during the world meeting in Lima, the movement was branded the Solidarity Economy (Poirier et al. 2018, 2). However, it was not until the 2008 financial crisis that policy makers acknowledged the importance of finding innovative solutions to the social and economic challenges brought by the crisis, and whit it the SSE started to gain prominence in the international agenda (Chaves and Demoustier 2013, 14). That moment was a turning point for the SSE because entities from the sector - contrary to the companies in the market- were not affected by the crisis, and maintained a positive development 
(Poirier et al. 2018, 3). The resilient character of the SSE is one of the fundamental aspects in the promotion of SSE as an alternative to the prevalent socio-economic development model.

Indeed, SSE contributes to the promotion of economic development by increasing employment opportunities, as well as social and credit services. SSE allows for the emergence of new public policies at all levels, and the recognition of a variety of actors inside the social economy sector (Chaves and Demoustier 2013, 14). Thus, considering the SSEs contributions to society and the economy, the need to strengthen the regulatory frameworks that help promote this sector is even greater.

The process of SSE recognition occurs in two different ways: topdown and bottom-up. Usually, the latter is the most common and the most legitimate. In this situation, a group of actors that identify themselves as part of the SSE demand its recognition from the State (Poirier 2016, 9). There are some examples of this scenario ${ }^{5}$ where the organization of an important group of SSE stakeholders resulted in the design of SSE legal frameworks or public policies. However, not in all cases the process has taken place from the local to the global level. In some countries, such as South Korea ${ }^{6}$, the march towards SSE's institutional and legal recognition has occurred vertically (UNRISD 2018).

In addition to these recognition processes, there are other elements that can support the visibility of the sector, such as the international networks that seek to make the sector visible throughout the world. For instance, the Intercontinental Network for the Promotion of Social and Solidarity Economy (RIPESS) brings together various regional networks ${ }^{7}$. Likewise, organizations such as CIRIEC international have emerged with the objective of promoting the study of SSE at the international level, creating chapters in many countries in Europe and Latin America ${ }^{8}$. Similarly, the United Nations and the International

5 Social Economy Act of Québec (Mendell 2007), Brazilian Global Forum (Espelt and Fransualdo 2018), and Wallonia Act (Coutiez and Moens 2013) are some examples of the role that entities have in the articulation of SSE sector around the world.

6 To learn more about South Korea's case, review UNRISD 2018.

7 The African Network of Social Solidarity Economy (RAESS), the Latin American Network (RIPESS LAC), the North American Network (RIPESS America from the North), the Asian Solidarity Economy Council, the European Solidarity Economy Network (RIPESS EU), and the Oceania Network (RIPESS Oceania) are some examples of the initiatives that have been generated internationally to promote the sector (RIPESS 2019).

8 CIRIEC International is an organization that promotes SSE. It was created in 1947 under the name of the International Center for Research and Information on Collective Economics in Geneva (CIRIEC 2007). 
Labor Organization (ILO) created an Inter-Agency Working Group on SSE (UNTFSSE), with the purpose of increasing the visibility of the SSE in the public policy and civil society sphere. The group is formed by nineteen United Nations and OECD agencies as full members and ten civil society representatives as observers. Education also plays a key role in spreading the importance of SSE. Thus, since 2010 the Academy of SSE was created with the objective of disseminating the experiences, challenges and best practices of the sector amongst policy makers and SSE professionals (ILO 2019). At the regional level, especially in Europe, there are other efforts, such as the 15071/15 European Union Council's Resolution acknowledging the importance of the social economy as an engine of employment in Europe. Another example is the Social Business Initiative (SBI), which was created with the aim of promoting a favorable climate for social enterprises in the region (EESC 2017, 15).

Usually, a successful process of SSE recognition is evidenced by the development of legal and institutional frameworks. However, the sphere of influence can be different in each case. Various efforts have been made to recognize the regulation of some entities that are part of the sector (cooperatives, mutual societies, foundations, social enterprises, etc.). In some countries, emphasis has been placed on cooperatives; in others, on foundations, mutual societies, associations or social enterprises. In some countries, the evolution of this legal framework has led to the creation of specific laws in support of the SSE. The objective of such framework is to integrate various actors as part of this economic sector. For a better understanding, it is relevant to explain that the support to the SSE has been developed in two ways: sectorial and the competence recognition.

Sectorial recognition refers to the importance of some entities to the SSE sector. Thus, some actors like cooperatives and mutual societies were more important during the first years of SSE recognition, as these entities integrated to the sector at that moment, or during that generation (Bouchard 2009) ${ }^{9}$. Recently, several movements and entities created to support the SSE sector are demanding the recognition and importance of this type of entities; such as unions, social movements, local organizations, charities, social enterprises, etc. As a result, each country has developed a legal framework to exclusively regulate certain sectors. For example, there are some types of acts regulating the cooperative sector (Argentina, Brazil, Uruguay), the third sector (South

9 Bouchard explains that some different generations of SSE entities emerged according to the historical context (2009). 
Korea), the social enterprise sector (Finland, Slovenia, Luxembourg, Italy), and the solidarity economy sector (Colombia, Venezuela, Ecuador, Honduras). The figure 1 shows some examples of countries and the development of the SSE sector from different types of sectorial approved acts:

Figure 1

\section{Evolution of SSE recognition in the legal framework at the international level}

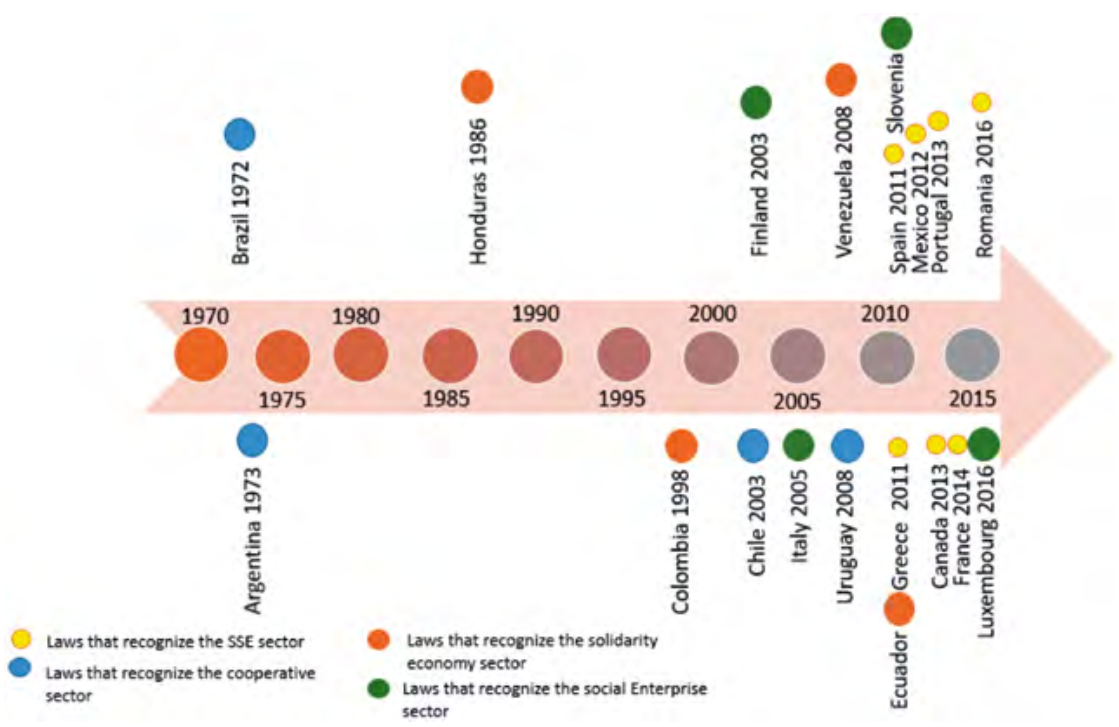

Source: Figure developed by the author with information about legal framework around the world.

Regarding the competence aspect, SSE recognition in the legal frameworks has been developed at different levels of territorial impact: national and regional. In the case of national recognition, the relevance is guided by the Constitutional credit of the sector in the country ${ }^{10}$ and the creation of the legal framework establishing the regulation,

10 The countries can appreciate the SSE role in their territories at the Constitutional level. This is the most important recognition that a country can offer. The Ecuadorian case is one of the very best examples of this, as Section 283 of the Constitution defines its vision based on Good Living definition of the State (Poirier 2016,3). 
promotion and evaluation of the sector through public policies. Countries like Spain, Mexico or France have developed this type of acknowledgement ${ }^{11}$. When it comes to the regional level, there is an increasing recognition of the contribution of the sector as well as an effort to regulate it and define the role of the Government in the promotion of the sector. The Québec province (Mendell 2007) and the Wallonia region (Coutiez and Moens 2013) are examples of the second type of legal framework developed for SSE recognition. Table 1 shows the differences between them and illustrates some examples of SSE support laws:

\section{Table 1}

Differences about the Legal framework on the SSE sector and the competence influence

\begin{tabular}{|c|l|l|}
\hline $\begin{array}{c}\text { Level of SSE } \\
\text { legal recognition } \\
\text { framework }\end{array}$ & \multicolumn{1}{|c|}{ Elements of this type of recognition } & $\begin{array}{c}\text { Examples of this } \\
\text { type of recognition }\end{array}$ \\
\hline Regional & $\begin{array}{l}\text { Recognizes the sector in some regions and } \\
\text { establish the role of the government. }\end{array}$ & $\begin{array}{l}\text { Québecprovince, } \\
\text { Wallonia region }\end{array}$ \\
\hline National & $\begin{array}{l}\text { Recognizes at Constitutional level. Creates } \\
\text { and approves a National legal framework } \\
\text { for recognition and regulation of the SSE } \\
\text { sector. }\end{array}$ & $\begin{array}{l}\text { Spain, Mexico, } \\
\text { France, Greece, } \\
\text { Romania, etc. }\end{array}$ \\
\hline
\end{tabular}

Source: Table developed by the author with information about the Legal Framework on the SSE sector.

In 1986 Honduras created and approved the Social Sector Act ${ }^{12}$, which is considered the first Law that tried to integrate a group of entities like a sector (social sector). Consequently, other countries tried to integrate diverse entities to distinguish the solidarity sector, such as Latin American countries since the 1990s until the end of $2010^{13}$. Following this period and in the aftermath of the social and economic

11 Spain approved the Social Economy Act in 2011. One year later Mexico approved the Law on Social and Solidarity Economy, and in 2014 France enacted the Social and Solidarity Economy Act.

12 Ley num. 24. 820 del Sector Social de la Economía de Honduras. Official Decrete number 193-85 October, 1985 (Republic of Honduras 1985)

13 Colombia, Venezuela and Ecuador are some examples of this initiative. 
crisis of 2008, the relevance of SSE increased ${ }^{14}$ and some countries established its importance through the formulation and implementation of legal frameworks for the SSE sector at the national level: Greece (2011), Spain (2011), Mexico (2012), Portugal (2013), France (2014), Romania (2016) ${ }^{15}$. It is important to mention that the value recognition for the SSE sector happened not just at the international level, but also at the regional level; for example, in the case of Québec (2013) ${ }^{16}$ and the Wallonia region $(2008)^{17}$.

Figure 2

\section{Legal framework supporting SSE at the international level}

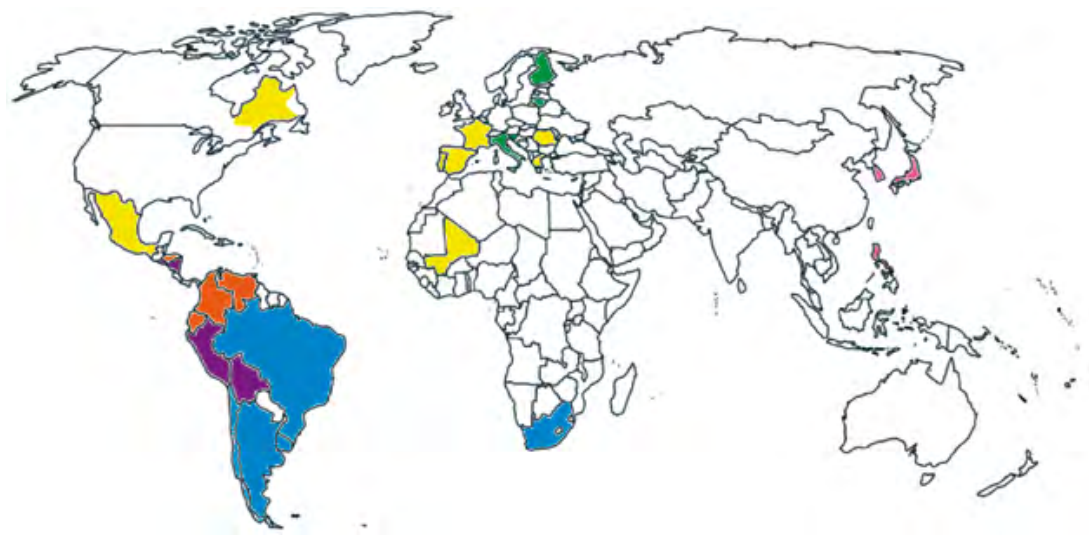

Source: Figure developed by the author with information of Socioeco site (http://www.socioeco.org) about the legal recognition of SSE and other legal frameworks mentioned before ${ }^{18}$

14 The reason why the SSE sector rose in importance in the aftermath of the economic crisis is due to the capacity of these type of entities to overcome economic crisis.

15 Law 4019/2011 in Greece (Hellenic Republic, 2011), Law 5/2011 in Spain, Law on Social and Solidarity Economy in Mexico (United Mexican States 2012), The French Law on the Social and Solidarity Economy 2014-86 (French Republic 2014), and the Law on Social Economy (no. 219) in Romania (Romanian Parliament, 2016).

16 Social Economy Act, Québec (National Assembly of Quebec 2013).

17 Décret régional relatif à l'économie sociale (The Walloon Parliament 2008).

18 All these legal frameworks support SSE in different sectors: in yellow recognizes the legal frameworks supporting SSE are recognized, in purple the food security legal frameworks are recognized. The orange color highlights areas where solidarity economy legal frameworks are recognized, while the green purports where social enterprise legal frameworks are recognized. Lastly, in pink color are the areas that recognizes the nonprofit organizations sector. 
Figure 2 shows countries that have currently approved some type of legal framework that supports SSE (could be sectorial and/ or competency level).

\section{Compared analysis from Social Economy Legal frameworks in America}

In the American continent, until September 2019, the legal frameworks purposely supporting SSE sector were found in Mexico at the national level, and Québec at the regional level. Nevertheless, there are other types of legal frameworks trying to support the sector, such as the solidarity economy. This position is a stronghold posture in the Latin American region, because it originated from the resistance of social movements during historic revolutionary events in the region ${ }^{19}$. According to Coraggio, the solidarity approach is an emancipatory force against the neoliberal system (2014). In general, the Latin American perspective in the implementation of SSE has been oriented in that emancipatory way.

Colombia began the recognition of the SSE sector through the creation of a legal framework for cooperatives since 1931, with the Law $134^{20}$. During the 1980s the State created the National Administrative Department of Cooperatives (DANCOOP for its acronym in Spanish). Supported by the United Nations for Development Program (UNDP) and the International Labor Organization (ILO), Colombia developed a National Plan for Cooperative Development ${ }^{21}$ (Martínez 2017, 181-184). The Constitutional recognition happened in 1991, highlighting the importance of solidarity as the most relevant principle in the country (Dávila et al. 2018; Martínez 2017). The law supporting

19 There are some examples of this movement in Latin America; for instance, the trade unions and cooperatives in Brazil that were relevant actors for the creation of the World Forum in 2003 (Espelt and Fransualdo 2018). Cooperative tradition in Argentina allowed the recovery of enterprises and a change in the imaginary idea of work (Hopp 2017; Faulk 2016). The first cooperatives in Chile tried to recognize fishers' rights in 1887 (Ministry of Economy and Tourism Promotion of Chile 2014). Social policies after the economic crisis in Uruguay in 2002 promote associative, solidary and cooperative work (Ministry of Social Development of Uruguay - MIDES for its acronym in Spanish2018, 41).

20 Ley 134 Sobre sociedades cooperativas. Year LXVII, N. 2186. 15, December, 1931. (Republic of Colombia 1931).

21 By that period the concept of solidarity economy was commonly used, and the actors of the sector were cooperatives as well other types of associative organizations. 
the SSE sector was approved in $1998^{22}$. This law establishes that the Colombian State will promote, develop and strengthen the solidarity sector in the country. In addition, it establishes the national bodies and programs that must to be created to promote the sector ${ }^{23}$.

The Mexican State started the cooperative recognition in 1873, with the foundation of the first cooperative. The development of the social sector has been an incredible effort by the cooperative movements and other civil society organizations ${ }^{24}$. Unfortunately, during these decades the government used the support of entities like cooperatives as a way of cronyism ${ }^{25}$ and corporatism. This is the reason why the cooperative movement in Mexico was neither legitimate nor truthful within the Mexican society. Nevertheless, one of the efforts has an effect on the social economy development in Mexico was the modification of article $25^{\text {th }}$ of the Constitution. Such modifications were approved in 1983, which identified the social sector as part of the national economy. However, at the time the national interests were aligned to the neoliberal policies so the approval of the social sector was used to justify some privatization aspects embedded within this constitutional article. One of the most important effects of this modifications was the creation in 1991 of the Fund and Program to Support Solidarity

22 Ley 454 de 1998 en lo relativo a la integración y funcionamiento del Consejo Nacional de la Economía Solidaria (CONES for its acronym in Spanish). Year cxxxiv. n.43357. August, 6, 1998 (Republic of Colombia 1998).

23 National Council of Solidarity Economy (CONES in Spanish), Fund for Promotion of Solidarity Economy (FONES in Spanish), and the National Administration for Social Economy Department (Dansocial in Spanish).

24 Through several articles, Rojas discusses about the historical process in Mexico that led to the Law on Social and Solidarity Economy. He explained that in 1917 the social sector was recognized in articles 28th and 123th of the Constitution. In 1927, the first law related to the sector was enacted. In 1938 the cooperative movement was recognized in a political way and the working class received such recognition as its organization form. The State assumed the control and as a result, a nationalist discourse and a populist government emerged. During the decades of 1940 to 1970 the cooperatives' development was halted by the government, until the administration of 1970, when old populist practices were promoted (Rojas 2006). At the end of the 1970s, The Intersectorial Comission for the Cooperative Strenght was created. This entity promoted a new Plan for Cooperatives at the beginning of the 1980s. The purpose of the Plan was to incorporate landless peasants to the market, provide jobs, and promote opportunities for marginalized zones as well. This plan was considered the most ambitious one from a technical and legal perspective, focusing on cooperative promotion (Rojas 2013).

25 Cronyism is a way in which the Mexican State tried to control the country by supporting the three main productive sectors domestically: workers' unions, education unions, and agricultural unions. 
Companies (FONAES for its acronym in Spanish). This institution aims to promote productive development focused on indigenous populations, agrarian and urban groups. The program's intent was not only to support SSE, but also small and medium businesses. In addition, the program was part of the Social Development Ministry, providing it an assistance perspective and thus, the SSE vision was misguided (Rojas 2016). An example of this assistance perspective is the political policy emerged after the neoliberalist measures of the 1980s, like Solidarity or Progresa ${ }^{26}$ conditional cash transfer programs. While they, aim to overcome poverty and inequality, the results were not as good as the desired outcomes. With these new policies the relevance on SSE in Mexico significantly disappeared until 1994, when some efforts prompted the first draft of the Law on Social and Solidarity Economy, approved in $2012^{27}$.

\subsection{Legal frameworks}

Colombia 28 and Mexico 29 have developed legal frameworks for the recognition of SSE ${ }^{30}$. Table 2 shows the legal framework analysis that has been implemented in each case with the purpose of promoting SSE. This table shows that both countries have a defined objective with regards to the regulation of the SSE sector. Nevertheless, Colombia established this legal framework to transform an existing entity into a new one focused on solidarity economy ${ }^{31}$. Something similar occurred in Mexico. Prior to the approval of the Law on Social and Solidarity

26 Economic Comission for Latin America and the Caribbean (ECLAC) analyzes programs that seek to overcome poverty. In the Mexican case is analyzed for both different programs: the National Solidarity Program (PRONASOL in Spanish) and the Education, Health and Food Program (PROGRESA in Spanish), which were carried out during the period 1988-2002. The study concludes that although this type of transfer program improves the living conditions of people living in poverty, it is not an adequate strategy to reduce poverty since it does not generate an income difference in this sector of the population (ECLAC 2003).

27 For more information about the historical context for the juridical construction of SSE in Mexico review Rojas (2016).

28 Ley 454 de 1998 (Republic of Colombia 1998).

29 Ley de la Economía Social y Solidaria en lo referente al Sector Social de la Economía. Diario Oficial de la Federación 3-05-2012. (United Mexican States 2012).

30 There are different types of support of SSE in America, as we mentioned before. Just in the case of these countries, the recognition is in the SSE sector.

31 From National Administrative Department of Cooperatives in the National Department of Solidarity Economy (Law 454). 
Economy, the FONAES institute supported productive projects, but it later disappeared. It seems like the new legal framework for support the SSE only changed the name to the new institution ${ }^{32}$.

Secondly, both countries established Constitutional recognition of the SSE. This type of recognition is considered the most important aspect that a State can give to the sector, because it furthers the visibility of SSE and the development of public policies to promote SSE at the national level. Without such fundamental element, all SSE promotion is hopeless. Colombia recognizes the solidarity aspect as a main value in the nation, on the $1^{\text {st }}$ Constitutional article. In article 25 of the Constitution Mexico acknowledges the need to have three different types of sectors to promote economic development: private, public, social; which are on an equal footing.

Regarding SSE actors, it can be noted that the recognition of the diverse entities that integrate SSE is more developed in Colombia, and that could be a reason for better visibility in legal terms ${ }^{33}$. In both countries the associated work cooperatives, agricultural associations, and societal cooperatives are recognized as part of the sector. In the case of Colombia, the State also recognizes entities such as mutual associations, employee funds, popular housing organizations, auxiliary institutions of the solidarity economy, solidarity health companies, economies of ethnic groups, networks of solidarity collaboration, other associations, corporations, foundations, communal organizations, and volunteers. Thus, it means that Colombia acknowledges several entities in the SSE sector. On the contrary, in the case of Mexico there are five different entities that the State recognizes as part of the SSE sector, and adds a point where the law specifies that a SSE entity could be any entity that satisfies social needs. This is a distinctive aspect of the law, because under this justification some civil society actors that

32 In Mexico the Fund for productive projects in the agricultural area was the National Support Fund for Solidarity Companies (FONAES for its acronym in Spanish). The objectives of this entity was very similar to the first proposal of the new Institution that promotes social economy in Mexico: National Institute for Social Economy (INAES for its acronym in Spanish).

33 According to the Law 454/1998 of Colombia, solidarity organizations are "cooperatives, the second and third grade organizations that group cooperatives or other associative and solidarity forms of property, the auxiliary institutions of the solidarity economy, community enterprises, solidarity health enterprises, precooperatives, employee funds, mutual associations, the service companies in the forms of cooperative public administrations, the associative work companies and all those solidarity associative forms that meet the characteristics mentioned in this chapter" (Article 5, paragraph 2). 
create social benefits and are not integrated into the SSE sector ${ }^{34}$ can be excluded. Dávila et al notes the same situation in the Colombian case, as many actors have not been considered in the sector (2018). For that reason, it could be said that usually, legal frameworks are not considering all entities in the sector and exclude some actors, which leads us to the question whether there is a particular interest underlying these decisions.

In the case of promotion mechanisms, at the federal level both countries have special representation bodies and funds to promote SSE. Additionally, they support the creation, strengthening, technical assistance and training of social sector entities. The difference between them is how each country approaches the responsible area of representation. Colombia decided that the Special Administrative Unit of Solidarity Organizations has to be part of the Ministry of Labor ${ }^{35}$, while the Mexican State specifies that the National Institute for Social Economy (INAES for its acronym in Spanish) is part of the Ministry of Social Development. The analysis of this aspect is very revealing for future conclusions because it allows us to look at the focus of both governments in terms of public policies and whether there would be a difference if the current government changes ${ }^{36}$.

In terms of the evaluation mechanisms, they are established by the countries in both cases. The difference is the method by which each State implements these evaluation mechanisms. Colombia defines that it will be a meeting between three different public representation bodies: The Special unity, the Planning Department and the Agency that promotes Science and Technology in the country (COLCIENCIAS for its acronym in Spanish). These bodies will be according to a design for the evaluation of the program at the beginning of the fourth year of implementation. In the case of Mexico, the Council for the Evaluation of Social Policies is charged with running the evaluation.

34 Probably one of the main reasons for this is the challenges that the cooperative movement faced in its recognition process and which Rojas explained trough an historical analysis of the context (2016).

35 Since the implementation of the Law 454, the relevance of the National body that promotes SSE in Colombia has decreased. It started as CONES (with the approval of the Law) and fourteen years later it became a Special Administrative Unit of Solidarity Organizations within the Ministry of Labor (Dávila et al. 2018)

36 Corragio sustains that one of the biggest problems for SSE in Latin America is the Personalized Government, which creates a specific way of running the State, without an authentic National Plan (2014). 


\section{Table 2}

Similarities and differences between the legal framework in Colombia and Mexico

\begin{tabular}{|c|c|c|}
\hline & Similarities & Differences \\
\hline Objectives & $\begin{array}{l}\text { Defined structure for } \\
\text { SSE consolidation }\end{array}$ & $\begin{array}{l}\text { COLOMBIA-Determines conceptual } \\
\text { framework and constitute CONES }\end{array}$ \\
\hline \multirow{2}{*}{$\begin{array}{l}\text { Constitutional } \\
\text { recognition }\end{array}$} & \multirow{2}{*}{$\begin{array}{l}\text { Both countries recognize } \\
\text { SSE in their constitutions }\end{array}$} & $\begin{array}{l}\text { COLOMBIA-Recognizes that Colombia } \\
\text { as a country is based on people's } \\
\text { solidarity in article } 1 .\end{array}$ \\
\hline & & $\begin{array}{l}\text { MEXICO-Recognizes that national } \\
\text { development involves social sector in } \\
\text { article } 25 \text {. }\end{array}$ \\
\hline SSE actors & $\begin{array}{l}\text { Both countries recognize } \\
\text { a s s o ciat e d w o rk } \\
\text { cooperatives, agricultural } \\
\text { associations, and } \\
\text { societal cooperatives as } \\
\text { SSE actors }\end{array}$ & $\begin{array}{l}\text { COLOMBIA-mutual associations, } \\
\text { employee funds, popular housing } \\
\text { organizations, auxiliary institutions of } \\
\text { the solidarity economy, solidarity health } \\
\text { companies, economies of ethnic groups, } \\
\text { networks of solidarity collaboration, other } \\
\text { associations, corporations, foundations, } \\
\text { communal organizations, volunteers } \\
\text { MEXICO-communities, ejidos. }\end{array}$ \\
\hline $\begin{array}{l}\text { Promotion } \\
\text { mechanisms }\end{array}$ & $\begin{array}{l}\text { Promotion of national } \\
\text { bodies. } \\
\text { Promotion Funds. } \\
\text { Training. } \\
\mathrm{Creat} \text { i o n a n d } \\
\text { strengthening of entities. }\end{array}$ & $\begin{array}{l}\text { COLOMBIA-Special administrative unit } \\
\text { of solidarity organizations, within the } \\
\text { Ministry of Labor } \\
\text { MEXICO-National Institute of Social } \\
\text { Economy, within the Ministry of Social } \\
\text { Development }\end{array}$ \\
\hline $\begin{array}{l}\text { Evaluation } \\
\text { mechanisms }\end{array}$ & $\begin{array}{l}\text { Both entities have } \\
\text { evaluation tools }\end{array}$ & $\begin{array}{l}\text { COLOMBIA-Three public bodies: } \\
\text { Special administrative unit of solidarity } \\
\text { organizations, Planning Department and } \\
\text { COLCIENCIAS (Science and Technology } \\
\text { Ministry). } \\
\text { MEXICO-National Council for the } \\
\text { Evaluation of Social Development Policy } \\
\text { (CONEVAL in Spanish) evaluates the } \\
\text { program. }\end{array}$ \\
\hline
\end{tabular}

Source: Table developed by the author with information from: National Plan for the Promotion of the Solidarity Economy and Rural Cooperative 2017-2032 of Colombia (Government of Colombia 2017); Law 454 of 1998 regarding the integration and operation of the National Council of the Solidarity Economy of Colombia; National Development Plan 2019-2024 of Mexico (Government of Mexico 2019), and Law on Social and Solidarity Economy of Mexico. 


\subsection{Public policies}

When public policies are implemented it is necessary to consider some elements in the process. On the one hand, decision makers and national policy makers must be convinced of the relevance of creating SSE public policies. On the other hand, we must consider that the most appropriate instruments for the execution of such policies are identified and applied within the State at each level. Different types of instruments can be used for the promotion of the sector. SSE is considered a different business sector from the economies. In addition to that -the social economy can be considered as a collective objective by itself - when one thinks of it as a social and economic model to which one aspires; or, on the other hand, as an instrument to achieve common goals, such as social cohesion, financial inclusion or social innovation (Chaves 2013, 60-67).

In Table 3, we can see the similarities and differences of both analyzed countries in terms of their public policies. If we observe the discourse that both countries used in their National Plans, we could see that both of them apply phrases like "instrument for integration and socioeconomic revitalization" (Colombian case) and "economic recovery and the focus on the internal market, and the importance of employment" (Mexican case). These examples could reflect that SSE is considered as an instrument to achieve some goals, regardless of the fact that both Legal frameworks specify that the main goal of SSE is integral human development. One of the main challenges for the SSE policy makers is to understand its potential, and that means going beyond the constraints of its role into just one dimension (UNRISD 2018).

The inclusion of the SSE in public policies is observed at two levels: the structural-constitutional and the programmatic. In the case of the structural-constitutional level, it refers to the recognition given at the highest legal level. That is to say, in the recognition of the positive contribution that the SSE has for the State and therefore makes it explicit in the Constitution or some Treaty (Chaves 2013, 62). Some of these examples include the case of Spain in the European continent, or the case of Ecuador in the Americas. In the case of the programmatic level, it is explained that its inclusion is promoted through programs that have a medium term duration, such as national plans or regional development plans, directed by the government at different levels. The first edition of the Hands-to-Work program of Argentina ${ }^{37}$ is an

37 The Argentinian case seems to be one of the most interesting exceptions at the international level since the State does not have a legal framework for SSE sector recognition, just for the cooperative sector. However, it maintains a series of measures and public policies that promote the SSE in the country. 
example presenting an alternative to the lack of employment during the 2001 crisis. If we observe the public policies of the analyzed States, we could affirm that both of included the recognition at the Constitutional level (Colombia in the article 1 and Mexico in the article 25 of their respective national Constitutions). The difference is that Colombia recognizes solidarity as a main principle of society, while Mexico specifies that economic development is caused by three different sectors in the country: private, public and social, giving the same importance to the social sector than to the private and public. In the case of the programs, we could see the defined programs of SSE promotion as mentioned before.

There are two different groups of SSE promotion policies. On the one hand, there are soft policies, which focus on establishing a favorable environment in where companies in the sector can emerge, operate, and develop. On the other hand, there are hard policies, which seek to strengthen companies as constituted businesses (Chaves 2013, 67). Soft policies are divided into two groups: those of the institutional type and those of the cognitive type. When it comes to institutional measures, we talk about the institutionalization of the economy through the economic and legal system, that is: to recognize its identity and make it visible; to recognize the ability of these types of companies to operate in any sector and eliminate regulatory obstacles; to recognize the ability of SSE entities to participate in the design and implementation of public policies; and to establish SSE specialization bodies in public administration (Chaves $2013,68)$. The legal framework that each country established is the best example of the latter. The national bodies (UAEOS and INAES) and the public policies specifying each framework illustrate those efforts to promote institutionalization through programs such as the Programme for the promotion of the social economy in Mexico and the Integral Intervention Program in Colombia.

In the case of cognitive-type policies, they focus on influencing the cultural aspect. This is evidenced in the training and research carried out on the topic of SSE at the international level. For instance, CIRIEC International promoted every two years since 2007 an international congress that brings together academics, students, companies and organizations to discuss the topic of SSE, as well as country initiatives in the subject, such as the specialty of the University of Valencia in Spain. In the case of Colombia, there are at least 20 different solidarity economy courses created between 2011-2018 (Organizaciones Solidarias 2018), and the creation of diffusion platforms like the Observatory of the Social Sector of the Economy in Mexico are examples of the efforts undertaken by each country to spread the value of the SSE sector. 


\section{Table 3}

Similarities and differences between public policies implementation in Colombia and Mexico

\begin{tabular}{|c|c|c|}
\hline & Similarities & Differences \\
\hline \multirow{2}{*}{$\begin{array}{l}\text { Structural / } \\
\text { programatic }\end{array}$} & \multirow{2}{*}{$\begin{array}{l}\text { National Plan specifying the } \\
\text { importance of the SSE }\end{array}$} & $\begin{array}{l}\text { Colombia establishes the solidarity } \\
\text { economy as an instrument for the } \\
\text { integration and socioeconomic } \\
\text { revitalization. There is a focus on } \\
\text { rural communities. The importance } \\
\text { of the sector is related to the Peace } \\
\text { Agreements. }\end{array}$ \\
\hline & & $\begin{array}{l}\text { Mexico establishes the importance } \\
\text { in the economic recovery, focus } \\
\text { on the internal market, and job } \\
\text { creation. It mentions the promotion } \\
\text { of modalities of fair trade and social } \\
\text { and solidarity economy }\end{array}$ \\
\hline $\begin{array}{l}\text { Soft policies: } \\
\text { institutional / } \\
\text { cognitive }\end{array}$ & $\begin{array}{l}\text { Training and the Research } \\
\text { are established in the legal } \\
\text { framework of both countries }\end{array}$ & \\
\hline $\begin{array}{l}\text { Hard } \\
\text { policies: } \\
\text { incentives }\end{array}$ & $\begin{array}{l}\text { Access to working capital and } \\
\text { financing instruments: land, } \\
\text { infrastructure, technology, } \\
\text { raw material, research in } \\
\text { innovation, science and } \\
\text { technology; market studies, } \\
\text { productimprovement/Access } \\
\text { to financing instruments: } \\
\text { low interest in credit lines, } \\
\text { subsidies, revolving funds, } \\
\text { incentives }\end{array}$ & $\begin{array}{l}\text { Colombia: } \\
\text { Certifications; differential measures } \\
\text { for access to programs and projects; } \\
\text { in taxes; in parafiscal payments }{ }^{38}\end{array}$ \\
\hline
\end{tabular}

Source: Table developed by the author with information from: National Plan for the Promotion of the Solidarity Economy and Rural Cooperative 2017-2032 of Colombia (Government of Colombia 2017); and the National Development Plan 2019-2024 of Mexico (Government of Mexico 2019).

38 An example of these incentives in the rural projects, which aim to incorporate the gender approach in organizational dynamics, through the creation of some type of certification. According to the Decree 2733 of 2012 by Ministry of Labor, the employers who work with women victims of proven violence, will have the right to deduct from income $200 \%$ of the value of salaries and social benefits paid. Additionally, this decree indicates the requirements that the employer will have to meet to make the benefit effective (Government of Colombia 2017). 
In the case of hard policies, incentives are designed so to simplify the economic processes experienced by companies or reduce obstacles. These incentives are observed both in the aspect of demand (market access) and supply (value chain competitiveness) (Chaves 2013, 68) and are part of the regulatory frameworks established by countries to identify the support that will exist for entities in this sector. At the international level, this aspect (regulatory frameworks) constitutes one of the main challenges that SSE faces (Utting 2018).

\section{Discussions of the analysis}

Understanding the different elements that structure the legal and political frameworks for the promotion of SSE makes it possible to identify the relationship between these frameworks and their capacity for transformation in society. The purpose of the law itself, sets a resolution on what the framework hopes to accomplish. In general the SSE support frameworks seek contribute to the visibility of the sector in each country, as well as to favor the entities that are part of SSE. When this is expected, and an adequate promotion structure exists, the result should be the support to entities that promote a social benefit, and with it an improvement in the social aspect. If we think about the social effects of legal-political frameworks and their capacity to transform realities, we can identify an interdependent relationship between Law and social change (Wróblewski 1993). Is it noticeable that this relationship occurs in two ways? The example of the promotion of SSE in both countries explains this last assumption. The evolution of the legal and political framework began with the recognition of the cooperative sector, caused by social movements at the national level. This effort promoted the generation of legal frameworks in support of the co-operative sector, which eventually extended to the organization of other entities and the demand for a new legal framework. Other entities have achieved this recognition.

Overall, both legal frameworks are very detailed, and this could be one of the reasons of the strong national body structures that implement those programs. At the international level, the analyzed legal frameworks in this article belong to the group of the most detailed frameworks, because they explain the type of national bodies that are necessary to promote SSE at the national level. They also specify the programs that must be implemented. Nevertheless, one of the questions that emerges with specific framework structure is the importance of detailed legal frameworks and the links to the 
efficient and effective public policies emanating from such frameworks. Coraggio (2014) affirms that in the case of Latin America, there are Presidential Governments that are more interested in their own approved and executed policies than in the National projects that guide the development of each country. The analyzed legal and political frameworks here show this situation when Colombia recognizes solidarity economy through a Law that establishes the structure of the national SSE body. However, after fourteen years, this department and its representation bodies have lost importance at the national level. Now there is an administrative unit within the Ministry of Labor that implements the policies. In the case of Mexico, the legal framework is also very exhaustive. The Law establishes the role of the national body for SSE promotion, the funds and the evaluation mechanisms. Although in this case, the situation of the Ministry in charge is one of the aspects to be evaluated as well. At the beginning of the program, INAES was part of Ministry of Economy, but after some years it was incorporated to the Ministry of Social Development. This is one of the most relevant elements to analyze, given that the funds can differ from one Ministry to another, and with that, the relevance of its societal impact can vary. The perspective that SSE maintains at the national level, be it a focus on economic development or social development impacts the role that SSE assumes in the country.

In addition, the social impact of the legal-political frameworks of SSE has different effects depending on the country analyzed. In the case of Mexico, during the last year the SSE promotion program has supported almost 40 thousand social entrepreneurs. The institution has invested 81.5 million dollars. This amount has funded 5099 productive projects, of which more than a half focus on women-led initiatives. Likewise 590 entities from young people (up to 29 years old) has been favored with 1,074,377 dollars (Instituto Nacional de la Economía Social 2018).

Colombia has developed 20 different educational programs about the solidarity economy. In addition, 4561 organizations were created or strengthened, and 38,837 homes were supported. Whitin those projects: 1,793 were allocated to afro descendent people, 5,093 for victims, 11,550 for women, 1,660 for indigenous people and 1,165 for people living with a disability. Over the last year, 4,238,282 dollars were injected to the program (Organizaciones Solidarias 2018). The difference in investment levels is relevant to the assumption that more funds correlated to more recognition. At the same, one of the most important questions emerges: What is the process of fund allocation like? While Mexico focus on entrepreneurs (40,000 social 
entrepreneurs), Colombia seems to have a more equitable way of allocating their funds as the money is provided to projects aiming to promote social inclusion.

The results show the effects of SSE recognition and implementation through public policies. Nevertheless, there are other aspects that can be analyzed from the frameworks. We cannot forget the strengths and weaknesses of each country in the evolution of each legal-political framework.

In the one hand, Colombia's strengths rely on the Law 454's establishment of a strong infrastructure to promote solidarity economy. Likewise, programmatic policies place the implementation of solidarity economy at the center, through the 2017-2032 National Development Plan. Besides, one of the most important aspect is the strategic place that solidarity economy has all over the National Development Plan. On the other hand, there are some weaknesses too. One of them is that, although there is a delimitation of evaluation mechanisms, it remains to be identified which indicators will be considered. Another one is that there are actors being excluded as part of the solidarity economy sector.

In the case of Mexico, a detailed evaluation system in the SSE Law specifies that an impartial entity should uphold the responsibility to evaluate. Having specialized institution leading the evaluation process is considered a success. Nevertheless, the institution is part of the actual administration, and one of the risk is viewing the evaluation process as a mechanism of control (Bouchard 2009). In addition to this, the State's National Plan encourages transversal support to the SSE from various national ministries that foster an integral perspective of the SSE. Nevertheless, the Law still shows a lack of integration of SSE actors on the legal framework.

In synthesis, it could be said that there are two main aspects to consider in the developed comparison: the role that SSE has in each country and how it materializes through legal frameworks and public policy implementation. Colombia has a more exhaustive development of legal frameworks, as well as a strategic role for the State, thanks to the relevance of SSE to the Peace Agreements. It is true that currently, the Mexican State shows a diversification of ways where SSE is encouraged through different Ministries (Social, Economy, Agriculture, etc.), as Colombia established with the role that SSE is given in the Peace Agreements. This should be one of the most important aspects that legal frameworks need to look at, because it gives SSE a more relevant role in the formulation of State policies. The potential that SSE has should be reinforced through diverse spheres in public 
administration, as many countries have tried to do in order to increase the positive effects of SSE in society (UNRISD 2018). In addition to that, an evaluation mechanism is one of the most noteworthy aspects that should also be researched (Bouchard 2009). In the case of Mexico, one of the most interesting aspects is the evaluation mechanism proposed by the legal framework, because it is one of the most developed at the regional level and it could offer some key elements in the SSE evaluation aspect.

According to the analysis, there are different elements that should be considered in order to propel the transformative potential of SSE. These elements could be listed as: Constitutional recognition, framework laws regulating the sector at a national level with specific objectives, sufficiently developed programs deployed according to the objectives laid out in the framework laws and development plans of each country, financing mechanisms, and evaluation mechanisms for providing constant feedback for their improvement. Finally, one of the most important aspects is the recognition of the capacity that entities of the sector can play in the design and implementation of public policies.

\section{Conclusions}

The analysis of the legal-political frameworks of the countries compared in this article outlines their importance to facilitate social transformation. In order to define internal processes that promote SSE sector at the domestic level, it is necessary to create regulatory frameworks that establish the rules of the game in each country. Each State has undergone its own evolutionary process towards the establishment of the SSE sector, starting the recognition of the cooperative sector. Over time, internal demands have led to an expansion of the SSE sector and therefore, to the development of relevant legal and institutional frameworks for the SSE. The formulation and design of legal and political frameworks is crucial in creating opportunities for entities that are part of the SSE sector to be able to transform local realities.

Although the creation of legal frameworks is part of the transformation processes, it is important to recognize that they are only one amongst many the necessary elements to prompt social changes. Many exogenous elements influence the process of social transformation in each country and impact the execution of public policies defined in the legal frameworks. One of the most important is the presidential style of public administrations in Latin American, as 
they develop personal governments more interested in pursuing their own goals than in advancing national plans. According to this analysis, some aspects are vital for the promotion of the sector in its entirety. In general, there is a lack of focus on the actors that make up the SSE and the applicable evaluation mechanisms. Perhaps this is a line of future research ${ }^{39}$, reviewing those evaluation processes and where they should be headed.

Through this article we can see the potential of SSE, but, in order to unleash the real potential of the sector to its full extent, governments should see SSE sector as a living body. They can achieve this by keeping in mind is the need to integrate all entities of SSE in the formulation and design processes of public policies and legal frameworks. Moreover, they should be mindful that SSE main aim is to guarantee social, economic, political and cultural rights more than it is uphold the national interest of any given administration. SSE has the potential to promote social cohesion and to be an innovative solution to overcome poverty, inequality and social exclusion. It is necessary to understand that SSE is transversal, and only transversal policies could harness the enormous potential of the SSE sector.

\section{References}

Bouchard, Marie J. (ed.). 2009. The Worth of the Social Economy. An international Perspective. Brussels: P.I.E. Peter Lang.

Castillo, Nadia E. 2017. "Los movimientos de economía social y solidaria en zonas de conflicto armado en México". In Congreso XXXI ALAS Uruguay 2017. Accessed July 21, 2019. http://alas2017.easyplanners.info/opc/ t//0168_nadia_eslinda_castillo.pdf

Castillo, Nadia E. 2018. Economía social en contextos de violencia: México y Colombia. Puebla, México: Universidad Iberoamericana Puebla.

Chaves, Rafael. 2013. "Social Economy and Public Policies. Elements of Analysis". In The emergence of the Social Economy in Public Policy. An international analysis, edited by Rafael Chaves, Danièle Demoustier, 57-72. Brussels: PIE Peter Lang.

Chaves, Rafael \& Demoustier, Danièle. 2013. The emergence of the Social Economy in Public Policy. An international analysis. Brussels: PIE Peter Lang.

39 One of the most important studies that UNRISD is researching is about the Sustainable Development Performance Indicators, that aims to identify the relevant methods and systems of measuring and assessment the achieving of SDG's. The purpose is to identify some indicators that could guide the current global challenges (UNRISD 2019). 
CIRIEC. International Centre for Research and Information on the Public, Social and Cooperative Economy. 2007. "50 years in Belgium from the Shores of Lake Geneva to the Banks of the Meuse. A relocation story". Accessed June 20, 2019. http://www.ciriec.uliege.be/wp-content/uploads/2016/01/ EN-CIRIECBrochure_1957-2007.pdf

Coraggio, José Luis. 2014. "Una lectura de Polanyi desde la economía social y solidaria en América Latina". In Cadernos Metrópole, 17-35.

Coutiez, Dimitri \& Moens, François. 2013. "Public Policies Supporting the Social Economy. The Specific Case of the Walloon Region (Belgium)". In The emergence of the Social Economy in Public Policy. An international analysis, edited by Rafael Chaves, Danièle Demoustier, 57-72. Brussels: PIE Peter Lang.

Dávila, Ricardo; Vargas, Amanda; Blanco, Lina; Roa, Edgar; Cáceres, Luz S. \& Vargas, Luis A. 2018. "Características de la economía solidaria colombiana. Aproximaciones a las corrientes influyentes en Colombia". In CIRIECEspaña, Revista de Economía Pública, Social y Cooperativa, 93: 85-113.

Economic Comission for Latin America and the Caribbean (ECLAC). 2003. La pobreza rural en América Latina: Lecciones para una reorientación de las políticas. Accessed October 25, 2019. https://repositorio.cepal.org/ bitstream/handle/11362/6544/S037467_es.pdf

Espelt, Ricardo \& Fransualdo, Francisco. 2018. "Evolución e impacto de la economía social y solidaria en Brasil y Cataluña: dos perspectivas". In XV Coloquio Internacional de Geocrítica. Las ciencias sociales y la edificación de una sociedad post-capitalismo, Accessed June 13, 2019. http://www.ub.edu/geocrit/XV-Coloquio/EspeltAzevedo.pdf

European Economic Social Committee (EESC). 2017. Recent Evolutions of the Social Economy in the European Union. Brussels: Visits and Publications Unit.

Faulk, Karen A. 2016. "'Recuperar el trabajo': Utopia and the Work of Recovery in an Argentine Cooperativist Movement". In The Journal of Latin American and Caribbean Anthropology, 21: 194-316.

French Republic. 2014. LOI n 2014-856 du 31 juillet 2014 relative à I'économie sociale. et solidaire. Accessed November 3, 2019. https://www. legifrance.gouv.fr/affichTexte.do?cidTexte=JORFTEXT000029313296

García, Alberto. 2009. "Marco legal de la economía social o solidaria según el movimiento de los trabajadores de América Latina." In RIDAA, 55: 47-67.

Government of Colombia. 2017. "PLANFES. Plan Nacional de Fomento a la Economía Solidaria y Cooperativa Rural". Accessed October 2, 2019. http://sitios.orgsolidarias.gov.co/PAZ/doc/Presentacion $\% 20$ Planfes $\% 20$ V31\%20Junio\%202018[1595].pdf

Government of Mexico. 2019. "Plan Nacional de Desarrollo 2019-2024." In Diario Oficial de la Federación del 12 de julio de 2019. Accessed October 8, 2019.https://www.dof.gob.mx/nota_detalle.php?codigo=5565599\&fec ha $=12 / 07 / 2019$

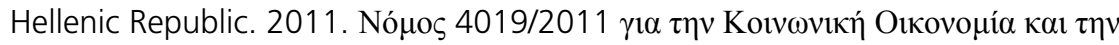

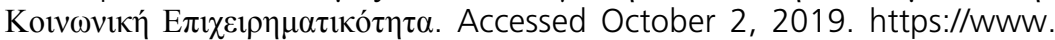
ypakp.gr/uploads/docs/4723.pdf 
Hopp, Malena V. 2017. "Políticas de promoción de la economía social en Argentina: desafíos para la construcción de una nueva institucionalidad." In Miradas sobre la economía social y solidaria en América Latina, edited by José Luis Coraggio, 19-62. Los Polvorines: Universidad Nacional de General Sarmiento. Accessed February 2, 2019: https://ediciones.ungs. edu.ar/wp-content/uploads/2017/10/9789876302913-completo.pdf

Intercontinental network for the promotion of social solidarity economy (RIPESS in spanish). 2019. Continental Networks. Accessed January, 21, 2019. http://www.ripess.org/?lang=en

International Labor Organization (ILO). 2019. Social and Solidarity Economy. Accessed October 23, 2019. https://www.ilo.org/global/topics/ cooperatives/projects/WCMS_546299/lang--en/index.htm

Instituto Nacional de la Economía Social. 2018. "Programa de Fomento a la Economía Social. Informe de Avance y resultados 2018." Accessed October 2, 2019. http://www.inaes.gob.mx/doctos/pdf/transparencia/ Rendicion_Cuentas/Avance\%20y\%20Resultados\%202018\%20PFES.pdf

Ley 5/2011, de 29 de marzo, de Economía Social. "BOE" núm. 76, de 30 de marzo de 2011. Accessed January 16, 2019. https://www.boe.es/buscar/ pdf/2011/BOE-A-2011-5708-consolidado.pdf

Martínez, Jarrison. 2017. "Políticas públicas para la economía solidaria en Colombia, antecedentes y perspectivas del posconflicto." In REVESCO Revista de Estudios Cooperativos, 123: 174-197.

Mendell, Marguerite. 2007. "La co-producción de políticas sociales en Quebec: el caso de la economía social." In La co-construcción de políticas públicas en el campo de la economía social, edited by Mirta Vuotto, 19-28. Buenos Aires: Prometeo Libros.

Ministry of Social Development of Uruguay (MIDES). 2018. "Uruguay Trabaja:10 años." Programa Uruguay Trabaja. 10 años. Una política activa de inclusión educativa y sociolaboral. Avances y desafíos. Accessed June 20, 2019. https://www.gub.uy/ministerio-desarrollo-social/comunicacion/ publicaciones/10-anos-de-uruguay-trabaja

Ministry of Economy and Tourism Promotion of Chile. 2014. "El cooperativismo en Chile". Accessed June 20, 2019. https://www.economia.gob. cl/2014/07/21/el-cooperativismo-en-chile.htm

National Assembly of Québec.2013. Loi sur l'économie sociale Québec. Loi no 27 (2013, chapitre 22). Accessed April 13, 2019. http://base.socioeco.org/ docs/loi_cadre.pdf

Poirier, Yvon. (2016). Reconocimiento jurídico y político de la economía social y solidaria (ESS). Panorama general y elementos de orientación. Accessed January 10, 2019. https://www.economiasolidaria.org/biblioteca/ reconocimiento-juridico-y-politico-de-la-economia-social-solidaria-ess

Poirier, Yvon; Wautiez, Françoise \& Alain, Béatrice. (2018). Legislación y políticas públicas a favor de la economía social y solidaria (ESS). Primeros pasos y elementos de una guía práctica. RIPESS, Socioeco, RELIESS. Accessed January 20, 2019. http://base.socioeco.org/docs/es-guia_ practica-ripess-pp-enero-2018_.pdf 
Republic of Colombia. 1931. Ley 134 Sobre sociedades cooperativas. Official Gazette, Year LXVII, N. 2186. 15, December, 1931. Accessed October 31, 2019. https://www.javeriana.edu.co/personales/hbermude/leycontable/ contadores/1931-ley-134.pdf

Republic of Colombia. 1998. Ley 454 de 1998 en lo relativo a la integración y funcionamiento del Consejo Nacional de la Economía Solidaria (CONES for its acronym in Spanish). Official Gazette. Year cxxxiv. n.43357. August 6, 1998. Accessed January 20, 2019. http://www2.congreso.gob.pe/sicr/ cendocbib/con2_uibd.nsf/03387DE9FA1C 194E05257B590078A3C9/\$FILE/ Olombia_Ley_454_1998.pdf

Republic of Honduras. 1985. Ley num. 24. 820 del Sector Social de la Economía de Honduras (Federal Official Gazzete. Official Decrete number 193-85 October, 1985). Accessed March 6, 2019. http://www.sice.oas.org/ SME_CH/HND/Ley_Sector_Social_Economia_193-85_s.pdf

Rojas, Juan José. 2006. "Marco Jurídico del cooperativismo en México: Desarrollo histórico y situación actual". In International Sysposium of the RULESCCOP Network. Challenges of the sector of cooperative and mutual organizations. Accesses December 3, 2019: http://www.facso.uchile.cl/ programas/proasocia/proyectos/rulescoop/talleres.html

Rojas, Juan José. 2013. "Panorama general del cooperativismo agropecuario en México". In Estudios Agrarios Magazine, 19: 121-138. Accessed September 21, 2019. https://biblat.unam.mx/es/revista/estudios-agrarios/ articulo/panorama-general-del-cooperativismo-agropecuario-en-mexico

Rojas, Juan José. 2016. "Reflexiones generales en torno al significado y alcances del reconocimiento constitucional de la existencia del sector social de la economía mexicana en el contexto del sector cooperativo". In Relaciones, 146: 251-281. Accessed December 3, 2019: http://www. scielo.org.mx/pdf/rz/v37n146/0185-3929-rz-37-146-00251.pdf

Romanian Parliament. Lege Nr. 219 din 23 iulie 2015privind economia socială (MONITORUL OFICIAL NR. 561 din 28 iulie 2015. Accessed October 5, 2019. http://www.mmuncii.ro/j33/images/Documente/Legislatie/L2192015.pdf

Organizaciones Solidarias. 2018. "Informe de Gestión 2011-2018. Colombia." In Organizaciones Solidarias, 30.

The Walloon Parliament. 2008. Décret du 20 novembre 2008 relatif à I'économie sociale - Région Wallonne. http://base.socioeco.org/docs/ decretes-rw_20081120_moniteur20081231.pdf

United Mexican States. 2012. Ley de la Economía Social y Solidaria, reglamentaria del párrafo séptimo del artículo 25 de la Constitución política de los Estados Unidos Mexicanos, en lo referente al Sector Social de la Economía. Diario Oficial de la Federación 3-05-2012. Accessed May 3, 2019. https://www.gob.mx/indesol/documentos/ley-de-la-economiasocial-y-solidaria-reglamentaria-del-p-octavo-del-art-25-de-la-constitucionpolitica-de-los-estados-unidos-mexicanos-197977

United Nations Research Institute for Social Development (UNRISD). 2018. Social and Solidarity Economy for the Sustainable Development Goals: 
Spotlight on the Social Economy in Seoul-Full Report. Accessed April 13, 2019. http://www.unrisd.org/80256B3C005BCCF9/httpNetITFramePDF?R eadForm\&parentunid=C271CADE934020E0C 1258315004C7DDF\&parent doctype=book\&netitpath=80256B3C005BCCF9/(httpAuxPages)/C271CAD E934020E0C1258315004C7DDF/\$file/Full-report---SSE-for-SDGs-in-SeoulReport-Final.pdf

United Nations Research Institute for Social Development (UNRISD). 2019. Sustainable Development Performance Indicators. Accessed May 20, 2019. http://www.unrisd.org/unrisd/website/projects.nsf/(httpProjects)/B2A0A8A 40BE9308CC12583350053ACDF?OpenDocument

Wróblewski, Jerzy. 1993. "Cambio del derecho y cambio social." In Instituto de Investigaciones Jurídicas. Accessed September 25, 2019. https:// revistas-colaboracion.juridicas.unam.mx/index.php/critica-juridica/article/ view/3080

Utting, Peter. 2018. "Achieving the Sustainable Development Goals through Social and Solidarity Economy: Incremental versus Transformative Change". In UN Inter-Agency Task Force on Social and Solidarity Economy. Accessed October 2, 2019. http://unsse.org/wpcontent/uploads/2018/04/ WorkingPaper1_PeterUtting.pdf 


\section{Copyright}

Deusto Journal of Human Rights / Revista Deusto de Derechos Humanos is an Open Access journal; which means that it is free for full and immediate access, reading, search, download, distribution, and reuse in any medium only for non-commercial purposes and in accordance with any applicable copyright legislation, without prior permission from the copyright holder (University of Deusto) or the author; provided the original work and publication source are properly cited (Issue number, year, pages and DOI if applicable) and any changes to the original are clearly indicated. Any other use of its content in any medium or format, now known or developed in the future, requires prior written permission of the copyright holder.

\section{Derechos de autoría}

Deusto Journal of Human Rights / Revista Deusto de Derechos Humanos es una revista de Acceso Abierto; lo que significa que es de libre acceso en su integridad inmediatamente después de la publicación de cada número. Se permite su lectura, la búsqueda, descarga, distribución y reutilización en cualquier tipo de soporte sólo para fines no comerciales y según lo previsto por la ley; sin la previa autorización de la Editorial (Universidad de Deusto) o la persona autora, siempre que la obra original sea debidamente citada (número, año, páginas y DOI si procede) y cualquier cambio en el original esté claramente indicado. Cualquier otro uso de su contenido en cualquier medio o formato, ahora conocido o desarrollado en el futuro, requiere el permiso previo por escrito de la persona titular de los derechos de autoría. 